\title{
Settled dust assessment in clinical environment: useful for the evaluation of a wider bioburden spectrum
}

Carla Viegas, Beatriz Almeida, Ana Monteiro, Inês Paciência, João Cavaleiro Rufo, Elisabete Carolino, Anita Quintal-Gomes, Magdalena Twarużek, Robert Kosicki, Geneviéve Marchand, Liliana Aranha Caetano \& Susana Viegas

To cite this article: Carla Viegas, Beatriz Almeida, Ana Monteiro, Inês Paciência, João Cavaleiro Rufo, Elisabete Carolino, Anita Quintal-Gomes, Magdalena Twarużek, Robert Kosicki, Geneviéve Marchand, Liliana Aranha Caetano \& Susana Viegas (2019): Settled dust assessment in clinical environment: useful for the evaluation of a wider bioburden spectrum, International Journal of Environmental Health Research

To link to this article: https://doi.org/10.1080/09603123.2019.1634799

Published online: 26 Jun 2019.

Submit your article to this journal

View Crossmark data $\asymp$ 


\title{
Settled dust assessment in clinical environment: useful for the evaluation of a wider bioburden spectrum
}

\author{
Carla Viegas ${ }^{\mathrm{a}, \mathrm{b}}$, Beatriz Almeida $\mathbb{D D}^{\mathrm{a}}$, Ana Monteiro ${ }^{\mathrm{a}, \mathrm{c}}$, Inês Paciênciad,e , João Cavaleiro Rufo ${ }^{\mathrm{d}, \mathrm{f}}$, \\ Elisabete Carolino ${ }^{a}$, Anita Quintal-Gomes ${ }^{a, g}$, Magdalena Twarużek ${ }^{\text {h }}$, Robert Kosicki ${ }^{\text {h }}$, \\ Geneviéve Marchandi, Liliana Aranha Caetano (D) a,j and Susana Viegas ${ }^{a, b}$
}

aH\&TRC- Health \& Technology Research Center, ESTeSL- Escola Superior de Tecnologia da Saúde, Instituto Politécnico de Lisboa, Lisbon, Portugal; ' ${ }^{b}$ Centro de Investigação em Saúde Pública, Universidade NOVA de Lisboa, Lisbon, Portugal; 'Escola Nacional de Saúde Pública, Universidade NOVA de Lisboa, Lisbon, Portugal; dPortugal \& Centro Hospitalar São João, Faculdade de Medicina da Universidade do Porto, Porto, Portugal; eInstituto de Ciência e Inovação em Engenharia Mecânica e Engenharia Industrial, Porto, Portugal; 'EPIUnit - Instituto de Saúde Pública, Universidade do Porto, Porto, Portugal; 9Faculty of Medicine, University of Lisbon Institute of Molecular Medicine, Lisbon, Portugal; ${ }^{h}$ Department of Physiology and Toxicology, Kazimierz Wielki University, Faculty of Natural Sciences, Institute of Experimental Biology, Bydgoszcz, Poland; 'Institut de recherche Robert-Sauvé en santé et sécurité du travail, Montréal, Canada; ${ }^{~}$ Research Institute for Medicines (iMed.ULisboa), Faculty of Pharmacy, University of Lisbon, Lisbon, Portugal

\begin{abstract}
The collection and analysis of settled dust samples from indoor environments has become one of several environmental sampling methods used to assess bioburden indoors. The aim of the study was to characterize the bioburden in vacuumed settled dust from 10 Primary Health Care Centers by culture based and molecular methods. Results for bacterial load ranged from 1 to 12 CFU. g $^{-1}$ of dust and Gram-negative bacteria ranged between 1 to 344 CFU.g ${ }^{-1}$ of dust. Fungal load ranged from 0 CFU.g ${ }^{-1}$ of dust to uncountable. Aspergillus section Fumigati was detected in 4 sampling sites where culture base-methods could not identify this section. Mucorales (Rhizopus sp.) was observed on $1 \mathrm{mg} / \mathrm{L}$ voriconazole. Three out of 10 settled dust samples were contaminated by mycotoxins. Settled dust sampling coupled with air sampling in a routine way might provide useful information about bioburden exposure.
\end{abstract}

\section{ARTICLE HISTORY}

Received 18 March 2019

Accepted 18 June 2019

\section{KEYWORDS}

Settled dust; exposure assessment; clinical environment; bioburden; mycotoxins

\section{Introduction}

Occupational exposure to bioburden, defined as microbial contaminants such as fungi and bacteria (Cabo Verde et al. 2015; Viegas et al. 2018a), in the workplaces is a major concern (Kettleson et al. 2015; Nevalainen et al. 2015) with increased relevance in clinical environments (Cabo Verde et al. 2015). Clinical settings must provide a clean and safe environment to protect patients and staff from nosocomial infections and occupational diseases (Leung and Chan 2006). Occupational Health and Indoor Air Quality (IAQ) studies have an important role in the exposure and risk assessment and, consequently, in management strategies (Cabo Verde et al. 2015).

Active and passive sampling methods have been used to characterize occupational exposure to culturable bioburden (Reponen 2017). However, although personal or stationary sampling of airborne bioburden can be performed to quantify exposure by inhalation, may be 
extensively influenced by environmental variables, such as seasonal variation and ventilation (Flannigan 1997).

Whereas passive-collection methods allow the collection of contamination over a longer period (days, weeks or several months), air samples can only reflect the load of a shorter period (mostly minutes) corresponding to the sampling duration (Badyda et al. 2016; Viegas et al. 2018b). Passive and active methods should, therefore, be used in parallel to ensure a more precise assessment of occupational exposure to bioburden (Reponen 2017; Viegas 2018). Increasing the number of different sampling methods will increase and enrich the data, enabling industrial hygienists to perform a more accurate risk characterization (Reponen 2017; Viegas 2018).

The collection and analysis of settled dust samples from indoor environments has become one of several environmental sampling methods used during bioburden evaluations by several researchers (Leppänen et al. 2018; Park et al. 2018). Settled dust has also been used for the assessment of mycotoxins contamination (Halstensen et al. 2006; Tangni and Pussemier 2007; Viegas et al. 2018e). In addition, settled dust was reported as an environmental support for bacterial development and is therefore considered a reservoir of bacterial contamination (Bouillard et al. 2005).

Passively settled dust can be sampled by directly vacuuming carpets, furniture or floors into filters, tubes or nylon sampling socks (Leppänen et al. 2014). The origins of bioburden in floor dust include the deposition of microbiota from outdoor air, humans, pets and pests, and also from growth in building material or furniture (Dunn et al. 2013). Settled dust can be used as an inhalation exposure surrogate marker as it presents the crucial feature of being less influenced by the short-term variability in indoor activities and ventilation (Meyer et al. 2004). The presence of bioburden in settled dust holds has an additional significance due to the possibility of dust-borne microorganisms and their metabolites to become resuspended and inhaled (Aleksic et al. 2017).

Culturable fungal loads exceeding $10^{5}$ colony forming units per gram (CFU.g ${ }^{-1}$ ) of dust collected from carpet or furniture surfaces have been suggested as evidence that an indoor environment has been contaminated with fungi (Hodgson and Scott 1999). However, the data from their control group is limited and may not be representative (Hicks et al. 2005). Besides this quantitative criteria, qualitative criteria should also be considered. Hodgson and Scott have proposed the identification of the present genera, particularly Penicillium sp. and Aspergillus sp., as indicators of indoor fungal contamination (Hodgson and Scott 1999). Non-problematic indoor environments do not present a dominant genera when three or more genera are present, unless Cladosporium or Alternaria genera are more prevalent (Hodgson and Scott 1999).

Airborne bioburden levels have already been described for some health care environments, such as hospital lobbies (Park et al. 2013), Portuguese operating theatres (Cabo Verde et al. 2015), bronchoscopy operating room (Marchand et al. 2016), patient rooms (Klánová and Hollerová 2003), haematological wards and surrounding areas (Tang and Wan 2013), and Portuguese hospital canteens (Viegas et al. 2011). However, until now, bioburden assessment has not been reported for Primary Health Care Centers in Portugal, even though patients attending such facilities routinely present a vulnerable health status.

The qualitative criteria, besides the quantitative, in the assessment of IAQ is of utmost importance in clinical settings, since not only different species may be related to different health outcomes, and the prevalence of antimicrobial resistance in human pathogens is also a global health challenge, with increased risk for subsequent occurrence of clinical diseases (up to 10-fold) (WHO 2016). The increasingly emergence of antifungal resistant Aspergillus sp., in the clinical context and in the environment should be considered (Perlin 2017). The increasing occurrence of cryptic species (i.e. morphologically indistinguishable species that can only be recognized by molecular phylogenetic methods and their DNA sequences) is also of concern as they may represent significant differences in the severity of diseases they cause (Lamoth 2016). The importance of cryptic species, often toxigenic (i.e. producers of mycotoxins) and/or drug resistant, reinforces the need to use complementary strategies, such as the measurement of mycotoxins or molecular detection of toxigenic species, for a broader characterization of the existent microbiota 
(Viegas et al. 2012). Therefore, using settled dust, which represents the cumulative indoor contamination of both bacteria and fungi (Meyer et al. 2004; Bouillard et al. 2005), for molecular detection and antimicrobial resistance should be considered in IAQ assessments (Viegas et al. 2017).

Thus, the aim of the study was to characterize the bioburden in settled dust from 10 Primary Health Care Centers by culture based and molecular methods. Additionally, screening of azoleresistance and mycotoxins detection was also performed to allow a detailed assessment of the bioburden. The data obtained will provide useful information for future recommendations and guidelines on occupational exposure and IAQ and support preventive actions to protect the health of healthcare workers and patients.

\section{Materials and methods}

\section{Primary health care centers assessed}

This exploratory study aimed to establish protocols to assess occupational exposure to bioburden in clinical settings. The study was conducted between June and September 2018 in 10 Portuguese Primary Health Care Centers (PHCC) located in the Lisbon district. The 10 assessed were the ones that accepted to participate in the study.

The sites selected for sampling (Table 1) were the ones classified as more critical regarding occupational exposure to bioburden (information retrieved by a walkthrough survey). Most PHCC were organized in two different zones: one used by the clinical staff and one used by the patients. In this study, the bioburden assessment was performed in the zone used by the workers, comprising different areas (Table 1). In each PHCC, a composite sample of settled dust was obtained covering different sampling areas and surfaces (Table 1). Additionally, dust from the vacuum bag used in all PHCC was collected at the end, for an additional characterization of the assessed PHCC.

A prior walkthrough survey was performed, as mentioned, to collect information regarding cleaning routines and procedures and to observe any type of water infiltration and fungal growth (Table 2). Sampling sites (floors and surfaces) are cleaned daily after patient service and working hours, and are performed by an external company. The treatment room due to the type of activity performed is cleaned several times a day by the workers of each PHCC or by an external company after working hours. The waste is collected, the floor is always cleaned and the surfaces when are visibly contaminated with organic fluids. The floor is cleaned with mop and surfaces with cloths. Some of the cleaning products contained disinfectants; however no information on the frequency and conditions of use (e.g. dilution factor) was obtained.

Table 1. Different areas covered by the composite sample in each PHCC.

\begin{tabular}{lcc}
\hline Areas & Number of covered areas & \multicolumn{1}{c}{ Surfaces } \\
\hline Medical office & $12^{\#}$ & $\begin{array}{l}\text { Chairs, floor, desk, cabinets, digital scales, skirting board, window } \\
\text { sills, door jamb, portable massage tables, keyboard, telephone, } \\
\text { computer and printer }\end{array}$ \\
$\begin{array}{l}\text { Technical office } \\
\text { Vaccination room }\end{array}$ & 10 & $\begin{array}{r}\text { Chairs, floor, desk, cabinets, digital scales, skirting board, window } \\
\text { sills, door jamb, keyboard, telephone, computer and printer } \\
\text { Chairs, floor, desk, cabinets, digital scales, skirting board, window } \\
\text { sills, door jamb, portable massage tables, keyboard, telephone, } \\
\text { computer and printer }\end{array}$ \\
$\begin{array}{l}\text { Treatment room } \\
\text { Chairs, floor, desk, cabinets, digital scales, skirting board, window } \\
\text { sills, door jamb, portable massage tables, keyboard, telephone, } \\
\text { computer and printer }\end{array}$ \\
$\begin{array}{l}\text { Corridor } \\
\text { Warehouse/Cleaning } \\
\text { room }\end{array}$ & 10 & $\begin{array}{l}\text { Floor and skirting board } \\
\text { Floor, skirting board, cabinets and workbench }\end{array}$ \\
\hline
\end{tabular}

\# PHCC 1 and 9 had 2 medical office assessed

* PHCC1 
Table 2. Vacuumed settled dust weights and cleaning routines and observations obtained during the walkthrough survey.

\begin{tabular}{|c|c|c|c|c|}
\hline $\mathrm{PHCC}$ & SETTLE DUST SAMPLES & $\begin{array}{l}\text { SETTLED DUST } \\
\text { WEIGHT (G) }\end{array}$ & CLEANING ROUTINES & OBSERVATIONS \\
\hline 1 & D-HU1 & 0.34 & All areas cleaned once a day & $\begin{array}{l}\text { Cracks on the walls of the } \\
\text { vaccination room }\end{array}$ \\
\hline 2 & D-HU2 & 0.3 & $\begin{array}{l}\text { All areas cleaned once a day } \\
\text { except treatments room } \\
\text { (cleaned twice) }\end{array}$ & $\begin{array}{l}\text { Visible mold growth in some } \\
\text { corridors }\end{array}$ \\
\hline 3 & D-HU3 & 0.75 & $\begin{array}{l}\text { All areas cleaned once a day } \\
\text { except vaccination } \\
\text { treatments rooms and } \\
\text { medical office (cleaned } \\
\text { twice) }\end{array}$ & $\begin{array}{l}\text { Cracks on the walls of the } \\
\text { vaccination room and treatments } \\
\text { room; visible mold growth in the } \\
\text { vaccination room and medical } \\
\text { office }\end{array}$ \\
\hline 4 & D-HU4 & 0.66 & $\begin{array}{l}\text { All areas cleaned once a day } \\
\text { except treatments room } \\
\text { (cleaned four times a day) }\end{array}$ & \\
\hline 5 & D-HU5 & 0.24 & $\begin{array}{l}\text { All areas cleaned once a day } \\
\text { except treatments room } \\
\text { (cleaned twice) }\end{array}$ & $\begin{array}{l}\text { Cracks on the walls and visible } \\
\text { mold growth in some corridors }\end{array}$ \\
\hline 6 & D-HU6 & 0.6 & $\begin{array}{l}\text { All areas cleaned once a day } \\
\text { except treatments room } \\
\text { (cleaned twice) }\end{array}$ & \\
\hline 7 & D-HU7 & 0.51 & $\begin{array}{l}\text { All areas cleaned once a day } \\
\text { except treatments room } \\
\text { (cleaned four times a day) }\end{array}$ & $\begin{array}{l}\text { Cracks on the walls in some } \\
\text { corridors }\end{array}$ \\
\hline 8 & D-HU8 & 0.48 & $\begin{array}{l}\text { All areas cleaned once a day } \\
\text { except treatments room } \\
\text { (cleaned twice) }\end{array}$ & Cracks on some walls and floors \\
\hline 9 & D-HU9 & 0.36 & $\begin{array}{l}\text { All areas cleaned once a day } \\
\text { except treatments room } \\
\text { (cleaned four times a day) }\end{array}$ & $\begin{array}{l}\text { Visible mold growth and cracks on } \\
\text { some walls }\end{array}$ \\
\hline 10 & D-HU10 & 1.52 & $\begin{array}{l}\text { All areas cleaned once a day } \\
\text { except treatments room } \\
\text { (cleaned twice) }\end{array}$ & $\begin{array}{l}\text { Visible mold growth and } \\
\text { discoloration on the walls of the } \\
\text { medical office }\end{array}$ \\
\hline
\end{tabular}

\section{Settled dust sampling}

Sampling of the settled dust was performed by a vacuum cleaner (HOOVER Brave BV71_BV10 A2, USA) equipped with a 40 micron nylon mesh inserted in a DUSTREAM ${ }^{\mathrm{TM}}$ collector (Indoor Biotechnologies, USA). Vacuuming was conducted for 10 minutes in different areas (Table 1) and a DUSTREAM $^{\mathrm{mi}}$ filter tube was collected in each PHCC $(\mathrm{n}=10)$. Settled dust was collected from several surfaces for a better representation of airborne contamination. The weight of the 10 PHCC dust samples was measured (Table 2) and analysed for microbial load and mycotoxins.

\section{Bioburden isolation}

The vacuumed dust (retained in the filter of nylon mesh) collected in each PHCC, as well as one piece $\left(2 \mathrm{~cm}^{2}\right)$ of the vacuuming bag used in all assessments, were used for bioburden characterization. All the samples were weighted and washed in a ratio of $1 \mathrm{~g}$ (dust) or $2 \mathrm{~cm}^{2}$ (vacuum bag) per $9.1 \mathrm{ml}$ of $\mathrm{NaCl} 0.9 \%$ with $0.05 \%$ Tween $80(10 \mu \mathrm{l})$ for $60 \mathrm{~min}$ at $250 \mathrm{rpm}$ and $0.15 \mathrm{~mL}$ of this suspension were spread onto four media: $2 \%$ malt extract agar (MEA) with 0.05 g.L . $^{-1}$ chloramphenicol media (Frilabo, Portugal); dichloran glycerol (DG18) agar-based media (Frilabo, Portugal); tryptic soy agar (TSA) with $0.2 \%$ nystatin (Frilabo, Portugal); and Violet Red bile agar (VRBA) (Frilabo, Portugal). Samples were also spread $(0.15 \mathrm{ml})$ onto Sabouraud agar media supplemented with $4 \mathrm{mg} \cdot \mathrm{L}^{-1}$ itraconazole, $1 \mathrm{mg} . \mathrm{L}^{-1}$ voriconazole, or $0.5 \mathrm{mg} . \mathrm{L}^{-1}$ posaconazole (protocol adapted from the EUCAST 2017 guidelines) (Frilabo, Portugal) (Arendrup et al. 2013) for the screening of antifungal resistance.

After incubation of MEA, DG18 and Sabouraud at $27{ }^{\circ} \mathrm{C}$ for 5 to 7 days for fungi and TSA and $\mathrm{VRBA}$ at $30{ }^{\circ} \mathrm{C}$ and $35{ }^{\circ} \mathrm{C}$ for 7 days for mesophilic bacteria and coliforms (Gram-negative 
bacteria), respectively, bioburden densities (colony-forming units, CFU.g ${ }^{-1}$ of dust or CFU.m ${ }^{-2}$ ) were calculated. Fungal species were identified microscopically using tease mount or Scotch tape mount and lactophenol cotton blue mount procedures. Morphological identification was achieved through macro and microscopic characteristics as noted by De Hoog et al. (2000).

When colonies overgrowth was observed due to fungi with fast growing rates (Chrysonilia sitophila), making it impossible to count colonies, a quantitative cut off was applied of $30 \mathrm{CFU}$ (highest counts of colonies on the 10 settled dust samples excluding Chrysonilia sitophila) to allow obtaining fungal densities.

Fungal biomass, Aspergillus/Penicillium/Paecilomyces and Aspergillus section Fumigati molecular detection

In average $10 \mathrm{mg}$ of dust was extracted in $200 \mu \mathrm{l}$ of PCR grade water using the Quick-DNA ${ }^{\mathrm{mx}}$ Fungal/Bacterial Miniprep Kit (Zymo-research corp, Irvine, CA, USA). For each extraction batch, a negative control of extraction was performed using only PCR grade water. The DNA extracts were kept at $-20^{\circ} \mathrm{C}$ until analysis. The primers and probes of the amplification systems used are shown in Table 3. The digital droplet PCR assay (ddPCR) was performed with a PCR reaction volume of $25 \mu \mathrm{L}$ using the $\mathrm{ddPCR}^{\mathrm{m}}$ Supermix for Probes (no dUTP) master mix (Bio-Rad, Hercules, CA) including $2 \mu \mathrm{L}$ of the template DNA. Positive controls were done in the same conditions with Penicillium digitatum or Aspergillus fumigatus DNA depending on the target assay. For the negative controls (NTC), the DNA was replaced by PCR grade water.

The fungal biomass, Aspergillus/Penicillium/Paecilomyces and the Aspergillus section Fumigati assays performed by dd-PCR were amplified in a Bio-Rad T-100 thermal cycler using the following cycling conditions: an initial denaturation step at $95^{\circ} \mathrm{C}$ for 10 minutes, followed by 40 cycles consisting of denaturation at $94^{\circ} \mathrm{C}$ for 30 seconds, annealing step at $49^{\circ} \mathrm{C}$ for Afumi and PenAsp or at $52^{\circ} \mathrm{C}$ for fungal biomass for 1 minute and extension at $72^{\circ} \mathrm{C}$ for 30 seconds, followed by a final extension step at $98^{\circ} \mathrm{C}$ for 10 minutes and a $12^{\circ} \mathrm{C}$ indefinite hold.

Amplicons (samples, NTC and PC) were immediately analyzed on the QX200 ${ }^{\mathrm{Tm}}$ Droplet Reader. Amplicons were classified as positive or negative according to a threshold manually set at 300 across all wells based upon results of the NTC and PC results. The QuantaSoft ${ }^{\mathrm{tw}}$ v.1.7.4.0917 (BioRad) software was used to calculate the concentration of each amplicon, along with their Poissonbased 95\% confidence intervals (Hindson et al. 2011).

In order to ensure reliable results, the manufacturer recommends to only analyze wells having more than 10,000 counted droplets, so only those were included in the analysis.

Molecular detection of other Aspergillus sections and Stachybotrys chartarum species complex

Molecular identification from specific species/strains recognized by their toxigenic potential was achieved by Real Time PCR (qPCR) using the CFX-Connect PCR System (Bio-Rad) on settled dust and vacuuming bag as previously indicated (Viegas et al. 2018c). 20ul Reactions included

Table 3. Primers and TaqMan ${ }^{\circledR}$ probe used in the dd-PCR for Aspergillus section Fumigati, Aspergillus/Penicillium/Paecilomyces and the global fungi assays.

\begin{tabular}{|c|c|c|c|}
\hline Target & Primers/probes names & Sequences & Reference \\
\hline \multirow{3}{*}{$\begin{array}{l}\text { Aspergillus section Fumigati (Aspergillus fumigatus } \\
\text { and Neosartorya fischeri) }\end{array}$} & AfumiF1 & 5'-GCC CGC CGT TTC GAC-3' & \multirow{3}{*}{$\begin{array}{l}\text { Haugland } \\
\text { et al. } 2002\end{array}$} \\
\hline & AfumiR1 & $\begin{array}{l}\text { 5'-CCG TTG TTG AAA GTT TTA } \\
\text { ACT GAT TAC-3' }\end{array}$ & \\
\hline & AfumiP1 & $\begin{array}{l}5^{\prime}-\mathrm{CCC} \text { GCC GAA GAC CCC AAC } \\
\text { ATG-3' }\end{array}$ & \\
\hline \multirow[t]{3}{*}{$\begin{array}{l}\text { Aspergillus/ } \\
\quad \text { Penicillium/Paecilomyces }\end{array}$} & PenAspF1 & $\begin{array}{l}\text { 5'-CGG AAG GAT CAT TAC TGA } \\
\text { GTG-3' }\end{array}$ & \multirow[t]{3}{*}{$\begin{array}{l}\text { Haugland } \\
\text { et al. } 2004\end{array}$} \\
\hline & PenAspR1 & $5^{\prime}-\mathrm{GCC}$ CGC CGA AGC AAC-3' & \\
\hline & PenAspP1 mgb & $5^{\prime}-$ CCA ACC TCC CAC CCG TG-3' & \\
\hline \multirow[t]{3}{*}{ Fungal biomass } & FungiQuant-F & $\begin{array}{l}\text { 5'-GGR AAA CTC ACC AGG TCC } \\
\text { AG-3' }\end{array}$ & \multirow[t]{3}{*}{ Liu et al. 2014} \\
\hline & FungiQuant-R & 5'-GSW CTA TCC CCA KCA CGA-3' & \\
\hline & FungiQuant-Probe & 5'-TGG TGC ATG GCC GTT-3' & \\
\hline
\end{tabular}

$\mathrm{R}=\mathrm{A}$ or $\mathrm{G}$ (puRine); $\mathrm{W}=\mathrm{A}$ or $\mathrm{T}$ (Weak $-2 \mathrm{H}$ bonds); $\mathrm{K}=\mathrm{G}$ or $\mathrm{T}$ (Keto) 
$1 \times$ iQ Supermix (Bio-Rad), $0.5 \mu \mathrm{M}$ of each primer (Table 4 ), and $0.375 \mu \mathrm{M}$ of TaqMan probe and $4 \mathrm{ul}$ of DNA template. Amplification followed a three-step PCR: 50 cycles with denaturation at $95^{\circ} \mathrm{C}$ for $30 \mathrm{~s}$, annealing at $52^{\circ} \mathrm{C}$ for $30 \mathrm{~s}$, and extension at $72^{\circ} \mathrm{C}$ for $30 \mathrm{~s}$. A non-template control was used in every PCR reaction. As positive controls of amplification, DNA samples were obtained from reference strains from the Mycology Laboratory from the National Institute of Health Doctor Ricardo Jorge (INSA).

\section{Mycotoxins analysis}

Ten settled dust samples and one filter from the dust bag were screened for mycotoxins presence. Settled dust samples $(0.20 \mathrm{~g})$ were extracted with $2.0 \mathrm{~mL}$ of $\mathrm{ACN}: \mathrm{H}_{2} \mathrm{O}$ : $\mathrm{AcOH}$ (79:20:1) for 90 minutes using Multi Reax shaker (Heidolph, Schwabach, Germany). Raw extracts were diluted with the same amount of water (total sample-to-solvent ratio was 1:20 (w/v), mixed, centrifuged and injected into the LC-MS/MS system. Detection of mycotoxins was carried out using high performance liquid chromatograph (HPLC) Nexera (Shimadzu, Tokyo, Japan) with a mass detector API 4000 (Sciex, Foster City, CA, USA).

Mycotoxins were separated on a chromatographic column Gemini NX-C18 $(150 \times 4.6 \mathrm{~mm}$, $3 \mu \mathrm{m}$ ) (Phenomenex, Torrance, CA, USA); mobile phase (A: water $+5 \mathrm{mM}$ ammonium acetate + $1 \%$ acetic acid, $\mathrm{B}$ : methanol $+5 \mathrm{mM}$ ammonium acetate $+1 \%$ acetic acid) mobile phase flow rate: $0.75 \mathrm{~mL} \cdot \mathrm{min}^{-1}$, injection volume: $7 \mu \mathrm{L}$. Several mycotoxins were assessed, namely: patulin, nivalenol, deoxynivalenol-3-glucoside, deoxynivalenol, fusarenon-X, $\alpha$-zearalanol, $\beta$-zearalanol, $\beta$-zearalenol, a-zearalenol, zearalanone, zearalenone, T2 tetraol, deepoxydeoxynivalenol, neosolaniol, 15acetyldeoxynivalenol, 3-acetyldeoxynivalenol, monoacetoxyscirpenol, diacetoxyscirpenol, aflatoxin M1, aflatoxin B1, aflatoxin B2, aflatoxin G1, aflatoxin G2, fumonisin B1, fumonisin B2, fumonisin $\mathrm{B} 3$, T2 triol, roquefortine $\mathrm{C}$, griseofulvin, T2 toxin, HT2 toxin, ochratoxin A, ochratoxin B, mycophenolic acid, mevinolin and sterigmatocystin. The limits of detection (LOD) and quantification (LOQ) obtained for each mycotoxin with the analytical method used are presented in Table 5.

The LOD (signal-to-noise ratio of 3) and LOQ (signal-to-noise ratio of 10), respectively, were calculated (using the 'S-To-N' script of Analyst ${ }^{\oplus} 1.6 .2$ software) by spiking blank dust extract at low concentrations.

\section{Statistical analysis}

The data were analyzed in the statistical software SPSS, v 23.0 for Windows. The results were considered significant at the significance level of $5 \%$. The Shapiro-Wilk test was used to test the normality of the data. Frequency analysis (n; \%), and the calculation of the minimum and maximum, were performed for the qualitative and quantitative data, respectively. Since the assumption of normality was not verified, the Spearman correlation coefficient was used to study the relationship between fungal load, fungal biomass and bacterial load and with the dust screened for fungal biomass assay and copies. $\mathrm{g}^{-1}$.

\section{Results}

\section{Bioburden characterization}

Results for bacterial load (in TSA media) in settled dust samples ranged from $1 \mathrm{CFU} \cdot \mathrm{g}^{-1}$ to 12 CFU.g ${ }^{-1}$, excluding one PHCC (PHCC 10) with uncountable result (Figure 1). Gram-negative bacteria load (in VRBA media) in settled dust samples ranged between 1 to $344 \mathrm{CFU} . \mathrm{g}^{-1}$, with PHCC 1 presenting the highest value (Figure 1). In the vacuuming bag sample, the bacterial load was $55 \times 10^{2}$ CFU.m ${ }^{-2}$ in TSA, and $25 \times 10^{2}$ CFU.m ${ }^{-2}$ in VRBA. 


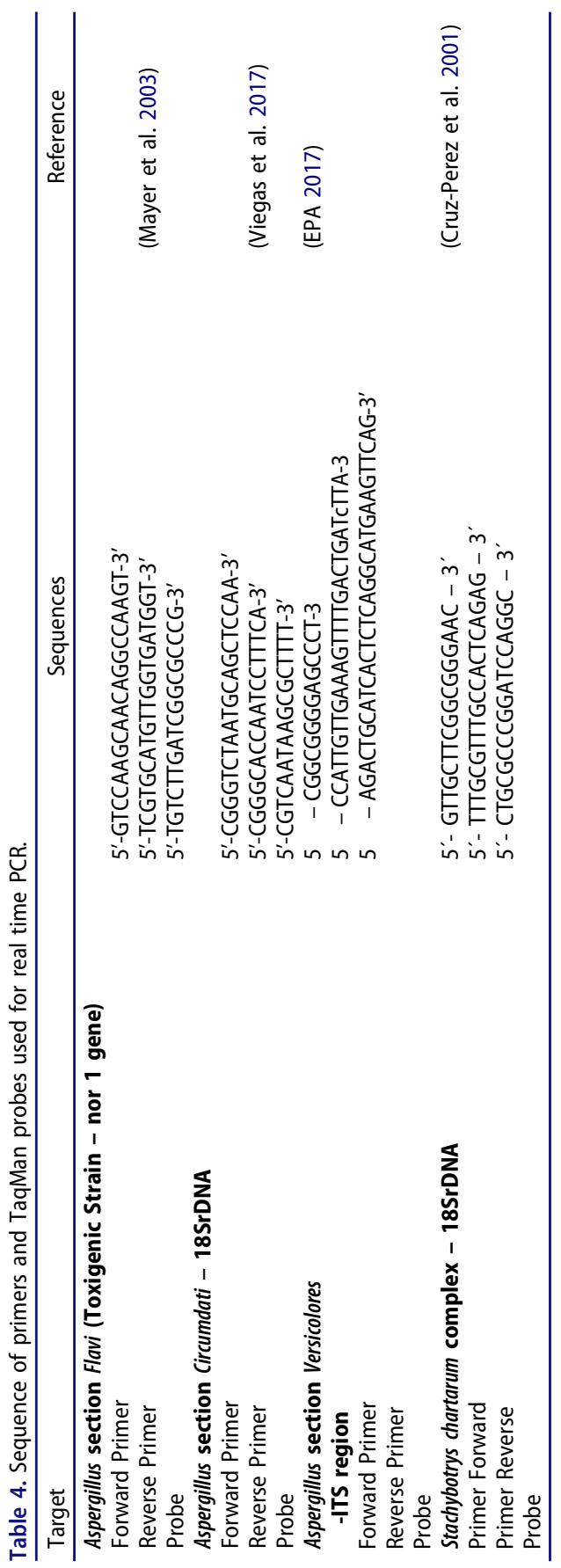


Table 5. Limits of detection (LOD) and quantification (LOQ) for dust samples.

\begin{tabular}{|c|c|c|}
\hline Mycotoxin & LOD ( $\mu$ g.kg-1) & LOQ $\left(\mu \mathrm{g} \cdot \mathrm{kg}^{-1}\right)$ \\
\hline Patulin & 2.5 & 8.4 \\
\hline Nivalenol & 10.8 & 36.0 \\
\hline Deoxynivalenol-3-glucoside & 12.6 & 42.0 \\
\hline Deoxynivalenol & 5.6 & 18.8 \\
\hline Fusarenon-X & 9.5 & 31.8 \\
\hline a-Zearalanol & 4.2 & 14.0 \\
\hline$\beta$-Zearalanol & 2.2 & 7.2 \\
\hline$\beta$-Zearalenol & 3.4 & 11.2 \\
\hline a-Zearalenol & 2.2 & 7.2 \\
\hline Zearalanone & 1.1 & 3.6 \\
\hline Zearalenone & 0.5 & 1.5 \\
\hline T2 Tetraol & 12.3 & 41.0 \\
\hline Deepoxydeoxynivalenol & 1.0 & 3.3 \\
\hline Neosolaniol & 0.4 & 1.2 \\
\hline 15-Acetyldeoxynivalenol & 2.3 & 7.6 \\
\hline 3-Acetyldeoxynivalenol & 2.1 & 6.9 \\
\hline Monoacetoxyscirpenol & 0.5 & 1.6 \\
\hline Diacetoxyscirpenol & 0.7 & 2.4 \\
\hline Aflatoxin M1 & 0.2 & 0.6 \\
\hline Aflatoxin B1 & 0.2 & 0.5 \\
\hline Aflatoxin B2 & 0.2 & 0.6 \\
\hline Aflatoxin G1 & 0.1 & 0.4 \\
\hline Aflatoxin G2 & 0.3 & 1.1 \\
\hline Fumonisin B1 & 1.6 & 5.3 \\
\hline Fumonisin B2 & 1.1 & 3.8 \\
\hline Fumonisin $\mathrm{B} 3$ & 1.4 & 4.6 \\
\hline T2 Triol & 0.9 & 3.0 \\
\hline Roquefortine $\mathrm{C}$ & 0.7 & 2.2 \\
\hline Griseofulvin & 0.4 & 1.2 \\
\hline T2 toxin & 0.4 & 1.2 \\
\hline HT2 toxin & 0.8 & 2.6 \\
\hline Ochratoxin A & 0.2 & 0.7 \\
\hline Ochratoxin B & 0.3 & 1.1 \\
\hline Mycophenolic acid & 0.7 & 2.2 \\
\hline Mevinolin & 0.4 & 1.2 \\
\hline Sterigmatocystin & 0.5 & 1.6 \\
\hline
\end{tabular}

Fungal load in settled dust samples ranged from 0 CFU.g ${ }^{-1}$ (PHCC 3) to uncountable (PHCC 2, 4, 8 and 9) in MEA, and in DG18 (PHCC 7 presented the lowest load and PHCC 1 and 6 the highest load) (Figure 1). The vacuuming bag sample presented total fungal loads of $37 \times 10^{3} \mathrm{CFU}$. $\mathrm{m}^{-2}$ in MEA, and $264 \times 10^{3}$ CFU.m ${ }^{-2}$ in DG18.

Nine different fungal species were found on MEA and 7 in DG18. In dust samples, Chrysonilia sitophila was the most prominent species found in MEA (57.42\%), and in DG18 the most common species was Penicillium sp. (36.17\%) (Table 6). In the vacuuming bag sample, the most common species in MEA were Cladosporium sp. and Penicillium sp. (48.65\%), and the most common species in DG18 was Cladosporium sp. (94.70\%).

In MEA, Aspergillus section Nigri was found in settled dust samples from PHCC 1 and 9 (1 CFU. $\left.\mathrm{g}^{-1}\right)$, Aspergillus section Fumigati in PHCC $6\left(2 \mathrm{CFU} \cdot \mathrm{g}^{-1}\right)$ and Aspergillus section Versicolores in PHCC 7 and 8 (1 CFU.g $\left.{ }^{-1}\right)$; Aspergillus sections Nigri and Versicolores $\left(5 \times 10^{2}\right.$ CFU.m $\left.{ }^{-2}\right)$ were also found in the vacuuming bag sample. In DG18, Aspergillus section Versicolores was found in the settled dust samples from PHCC 7 (1 CFU.g $\left.{ }^{-1}\right)$, and Aspergillus section Candidi $\left(4 \times 10^{3}\right.$ CFU.m $\left.{ }^{-2}\right)$ was found in the vacuuming bag sample (Table 6).

Table 7 shows the fungal distribution in settled dust and vacuuming bag samples through growth in azole-supplemented Sabouraud media as a screening tool for resistance. Eight different fungal species were found in Sabouraud (Alternaria sp., C. sitophila, Chrysosporium sp., Cladosporium sp., Aspergillus section Fumigati, Penicillium sp., Stemphilium sp. and Rhizopus sp.). Fungal growth in at least one azole-supplemented media was observed for 6 


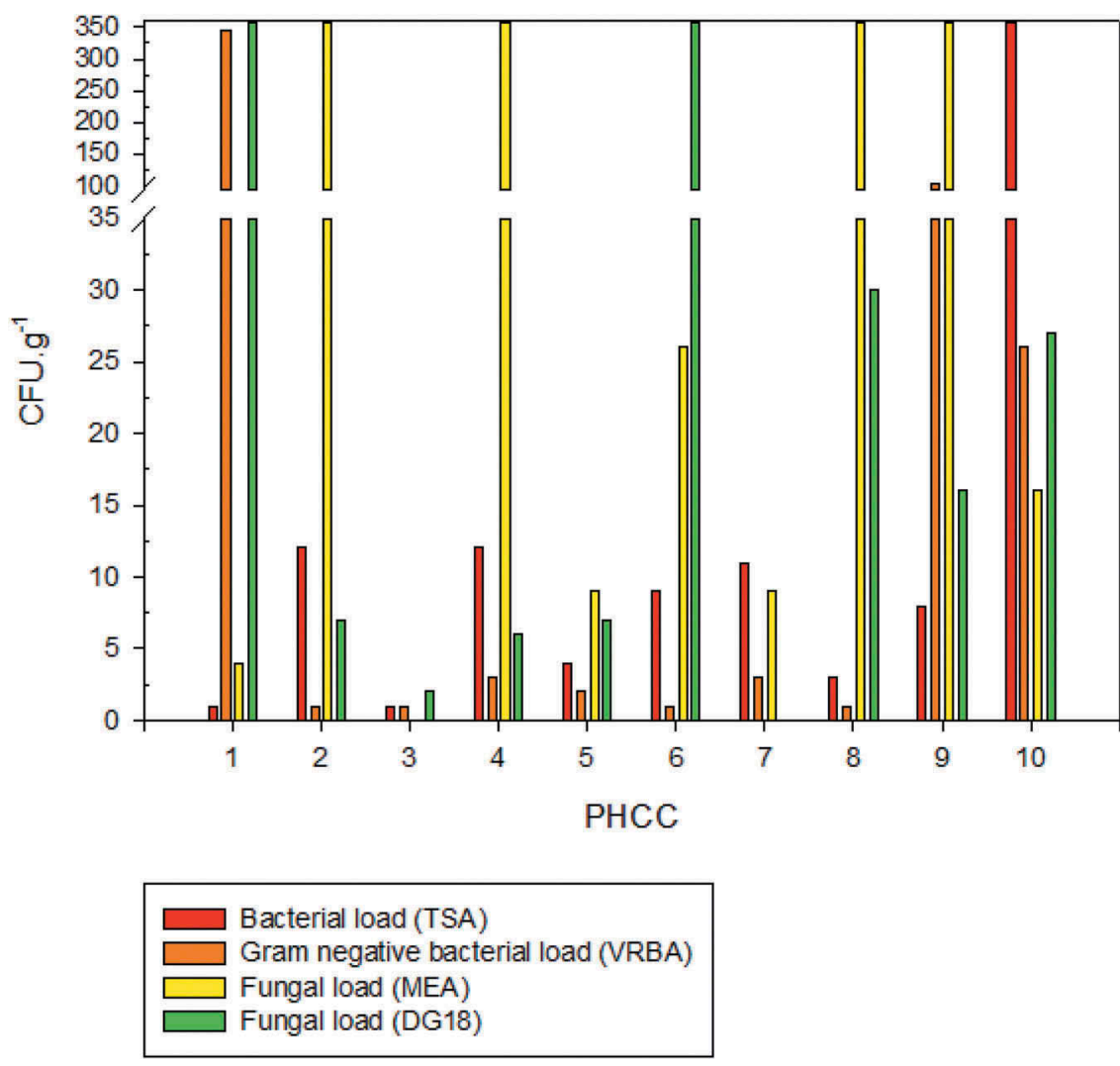

Figure 1. Bioburden obtained from settled dust samples from the 10 PHCC studied.

fungal species (Alternaria sp., C. sitophila, Chrysosporium sp., Cladosporium sp., Penicillium sp., and Rhizopus sp.) in settled dust samples from 7 out of 10 assessed PHCC (except for PHCC 3, 6 and 9).

The burden of Aspergillus (section Fumigati) was 3 CFU.g ${ }^{-1}$ (PHCC 9) on Sabouraud, with no growth observed in azole-supplemented media; the burden of Mucorales (Rhizopus sp.) was $3 \times 10^{3}$ CFU.m ${ }^{-2}$ (vacuuming bag) on $1 \mathrm{mg} / \mathrm{l}$ VORI only. Of note, fungal growth of Penicillium sp. was observed in ITRA and VORI in settled dust from PHCC 2 and 4 (ranging from 1 to 2 CFU.g ${ }^{-1}$ ), and in vacuuming bag sample (ranging from $15 \times 10^{2}$ to $65 \times 10^{2} \mathrm{CFU}_{\mathrm{m}}{ }^{-2}$ ).

Fungal biomass, Aspergillus/Penicillium/Paecilomyces and Aspergillus section Fumigati dd-PCR molecular detection assays

Fungal biomass levels were above the detection limit $(1$ copy $/ 2 \mu \mathrm{L})$ and varied from $3.76 \times 10^{4}$ to $6.00 \times 10^{6}$ copy.g $^{-1}$ (Figure 2). Aspergillus/Penicilliium/Paecilomyces levels were above the detection limits except in PHCC 7 and in the vacuuming bag. The levels in all the others PHCC varied from $9.88 \times 10^{3}$ to $1.83 \times 10^{6}$ copy.g-1 (Figure 2). Regarding the Aspergillus section Fumigati assay detection was positive in 5 of the 10 PHCC. The detected levels varied from $2.64 \times 10^{3}$ to $1.30 \times 10^{5}$ copy.g $\mathrm{g}^{-1}$ (Figure 2).

Molecular detection of specific Aspergillus sections and Stachybotrys chartarum species complex qPCR analysis of DNA directly extracted from the 10 settled dust samples revealed no detectable levels of the targeted Aspergillus species/complexes (Flavi, Versicolores or Circumdati) and from Stachybotrys chartarum complex. Aspergillus section Versicolores was detected on the vacuuming bag sample. 
Table 6. Fungal distribution on MEA and DG18 from all the settled dust samples.

\begin{tabular}{|c|c|c|c|c|c|}
\hline & \multirow[b]{2}{*}{ PHCC } & \multicolumn{2}{|c|}{ MEA } & \multicolumn{2}{|c|}{ DG18 } \\
\hline & & Species & $\begin{array}{c}\mathrm{n}\left(\mathrm{CFU} \cdot \mathrm{g}^{-1} / \mathrm{CFU}\right. \\
\left.\mathrm{m}^{-2}\right) ; \%\end{array}$ & Species & $\begin{array}{c}\mathrm{n}\left(\mathrm{CFU} \cdot \mathrm{g}^{-1} / \mathrm{CFU} .\right. \\
\left.\mathrm{m}^{-2}\right) ; \%\end{array}$ \\
\hline \multirow{32}{*}{$\begin{array}{l}\text { Settled dust } \\
\text { samples }\end{array}$} & \multirow[t]{3}{*}{1} & Penicillium sp. & $2 ; 50$ & C. sitophila & $30 ; 93.75$ \\
\hline & & Chrysonilia $s p$. & $1 ; 25$ & Cladosporium sp. & $2 ; 6.25$ \\
\hline & & $\begin{array}{l}\text { Aspergillus section } \\
\text { Versicolores }\end{array}$ & $1 ; 25$ & & \\
\hline & \multirow[t]{4}{*}{2} & C. sitophila & $30 ; 73.17$ & Ulocladium sp. & $4 ; 57.14$ \\
\hline & & Penicillium sp. & $9 ; 21.95$ & Cladosporium sp. & $3 ; 42.86$ \\
\hline & & Chrysosporium sp. & $1 ; 2.44$ & & \\
\hline & & Stemphilium sp. & $1 ; 2.44$ & & \\
\hline & \multirow[t]{2}{*}{3} & & & Penicillium sp. & $1 ; 50$ \\
\hline & & & & Cladosporium sp. & $1 ; 50$ \\
\hline & \multirow[t]{2}{*}{4} & C. sitophila & 30; 96.77 & Ulocladium sp. & $4 ; 66.67$ \\
\hline & & Aspergillus section Nigri & $1 ; 3.23$ & Penicillium sp. & $2 ; 33.33$ \\
\hline & \multirow[t]{4}{*}{5} & Penicillium sp. & $5 ; 55.56$ & Penicillium sp. & $4 ; 57.14$ \\
\hline & & Chrysosporium sp. & $2 ; 22.22$ & Cladosporium sp. & $2 ; 28.57$ \\
\hline & & Ulocladium sp. & $1 ; 11.11$ & Alternaria sp. & $1 ; 14.29$ \\
\hline & & Cladosporium sp. & $1 ; 11.11$ & & \\
\hline & \multirow[t]{3}{*}{6} & Penicillium sp. & $18 ; 69.23$ & C. sitophila & $30 ; 49.18$ \\
\hline & & Cladosporium sp. & $8 ; 30.77$ & Penicillium sp. & $19 ; 31.15$ \\
\hline & & & & Cladosporium sp. & $12 ; 19.67$ \\
\hline & \multirow[t]{4}{*}{7} & Penicillium sp. & $5 ; 55.56$ & & \\
\hline & & $\begin{array}{l}\text { Aspergillus section } \\
\text { Fumigati }\end{array}$ & $2 ; 22.22$ & & \\
\hline & & Chrysosporium sp. & $1 ; 11.11$ & & \\
\hline & & Cladosporium sp. & $1 ; 11.11$ & & \\
\hline & \multirow[t]{4}{*}{8} & C.sitophila & $30 ; 69.77$ & Penicillium sp. & $20 ; 66.67$ \\
\hline & & Penicillium sp. & $11 ; 25.58$ & Cladosporium sp. & $10 ; 33.33$ \\
\hline & & Aspergillus section Nigri & $1 ; 2.33$ & & \\
\hline & & Alternaria sp. & $1 ; 2.33$ & & \\
\hline & \multirow[t]{2}{*}{9} & C. sitophila & $30 ; 100$ & Penicillium sp. & $13 ; 81.25$ \\
\hline & & & & Cladosporium sp. & $3 ; 18.75$ \\
\hline & \multirow[t]{4}{*}{10} & Penicillium sp. & $12 ; 75.00$ & Cladosporium sp. & $17 ; 62.96$ \\
\hline & & Cladosporium sp. & $2 ; 12.50$ & Penicillium sp. & $9 ; 33.33$ \\
\hline & & Alternaria sp. & $1 ; 6.25$ & Aspergillus section & $1 ; 3.70$ \\
\hline & & $\begin{array}{l}\text { Aspergillus section } \\
\text { Versicolores }\end{array}$ & $1 ; 6.25$ & Versicolores & \\
\hline \multirow[t]{4}{*}{ Vacuuming bag } & & Cladosporium sp. & $18 \times 10^{3} ; 48.65$ & Cladosporium sp. & $25 \times 10^{4} ; 94.70$ \\
\hline & & Penicillium sp. & $18 \times 10^{3} ; 48.65$ & Penicillium sp. & $1 \times 10^{4} ; 3.79$ \\
\hline & & Aspergillus section Nigri & $5 \times 10^{2} ; 1.35$ & Aspergillus section & $4 \times 10^{3} ; 1.52$ \\
\hline & & $\begin{array}{l}\text { Aspergillus section } \\
\text { Versicolores }\end{array}$ & $5 \times 10^{2} ; 1.35$ & Candidi & \\
\hline
\end{tabular}

\section{Correlation analyses}

No significant correlations were observed between fungal biomass levels and bacteria counts, Gram - counts, fungal counts on MEA and DG18 (Table 8). However, although not significant, there were a correlation between higher levels of fungal biomass and lower counts of bacteria $\left(\mathrm{r}_{\mathrm{S}}\right.$ $=-0.316, \mathrm{p}=0.344)$, lower concentrations of fungal counts on MEA $\left(\mathrm{r}_{\mathrm{S}}=-0.326, \mathrm{p}=0.327\right)$ and higher concentrations of fungi on DG18 $\left(\mathrm{r}_{\mathrm{S}}=0.539, \mathrm{p}=0.087\right)$ (Table 8$)$.

\section{Mycotoxins contamination}

Three out of ten settled dust samples were contaminated by mycotoxins: one, the PHCC 9, with three mycotoxins (roquefortine C: $<2.2 \mu \mathrm{g} . \mathrm{kg}^{-1}$; griseofulvin: $<1.2 \mu \mathrm{g} . \mathrm{kg}^{-1}$; mycophenolic acid: $2.5 \mu \mathrm{g} \cdot \mathrm{kg}^{-1}$ ), and two with one mycotoxin each (PHCC 4, mycophenolic acid: $4.28 \mu \mathrm{g} . \mathrm{kg}^{-1}$; PHCC 8 , sterigmatocystin: $3.80 \mu \mathrm{g} \cdot \mathrm{kg}^{-1}$ ). 
Table 7. Fungal prevalence in azole-supplemented media from settled dust $\left(\mathrm{CFU} \cdot \mathrm{g}^{-1}\right)$ and vacuuming bag $\left(\mathrm{CFU} . \mathrm{m}^{-2}\right)$ samples.

\begin{tabular}{|c|c|c|c|c|c|c|}
\hline & & & $S A B$ & ITRA & VORI & POSA \\
\hline & PHCC & Species & $\overline{\mathrm{n}\left(\mathrm{CFU} \cdot \mathrm{g}^{-1}\right) ; \%}$ & $\overline{\mathrm{n}\left(\mathrm{CFU} . \mathrm{g}^{-1}\right) ; \%}$ & $\overline{\mathrm{n}\left(\mathrm{CFU} . \mathrm{g}^{-1}\right) ; \%}$ & $\mathrm{n}\left(\mathrm{CFU} . \mathrm{g}^{-1}\right) ; \%$ \\
\hline \multirow[t]{23}{*}{ Settled dust samples } & 1 & $\begin{array}{l}\text { Penicillium sp. } \\
\text { Cladosporium sp. }\end{array}$ & $\begin{array}{l}1 ; 50 \\
1 ; 50\end{array}$ & & $1 ; 100$ & \\
\hline & 2 & Penicillium sp. & $26 ; 87$ & $1 ; 100$ & $2 ; 100$ & \\
\hline & & Cladosporium sp. & $4 ; 13$ & & & $1 ; 100$ \\
\hline & 3 & Alternaria sp. & $3 ; 43$ & & & \\
\hline & & C. sitophila & $2 ; 29$ & & & \\
\hline & & Cladosporium sp. & $2 ; 28$ & & & \\
\hline & 4 & Chrysosporium sp. & $4 ; 80$ & & & \\
\hline & & Penicillium sp. & $1 ; 20$ & $1 ; 100$ & $1 ; 50$ & \\
\hline & & Alternaria sp. & & & $1 ; 50$ & \\
\hline & 5 & Penicillium sp. & $16 ; 94$ & $2 ; 0$ & & \\
\hline & 6 & $\begin{array}{l}\text { C. sitophila } \\
\text { Penicillium sn }\end{array}$ & $\begin{array}{c}1 ; 6 \\
10 \cdot 100\end{array}$ & $500 ; 100$ & & \\
\hline & 7 & $\begin{array}{l}\text { Penicillium sp. } \\
\text { Chrysosporium sp. }\end{array}$ & $8 ; 61$ & & & \\
\hline & & Cladosporium sp. & $3 ; 23$ & & & \\
\hline & & Penicillium sp. & $1 ; 8$ & $6 ; 100$ & & \\
\hline & & Stemphilium sp. & $1 ; 8$ & & & \\
\hline & 8 & Penicillium sp. & $9 ; 90$ & & & \\
\hline & & Chrysosporium sp. & $1 ; 10$ & $1 ; 100$ & & \\
\hline & 9 & Aspergillus section Fumigati & $3 ; 100$ & & & \\
\hline & 10 & Penicillium sp. & $12 ; 2$ & & $2 ; 67$ & \\
\hline & & C. sitophila & $500 ; 97$ & & & \\
\hline & & Alternaria sp. & $1 ; 0$ & & & \\
\hline & & Stemphilium sp. & $1 ; 0$ & & & \\
\hline & & Chrysosporium sp. & & & $1 ; 33$ & \\
\hline \multirow{3}{*}{$\begin{array}{l}\text { Vacuuming bag } \\
\text { (all PHCC) }\end{array}$} & & Penicillium sp. & $1000 ; 100$ & $6500 ; 93$ & $1500 ; 33$ & \\
\hline & & Chrysosporium sp. & & $500 ; 7$ & & \\
\hline & & Rhizopus sp. & & & $3000 ; 67$ & \\
\hline
\end{tabular}

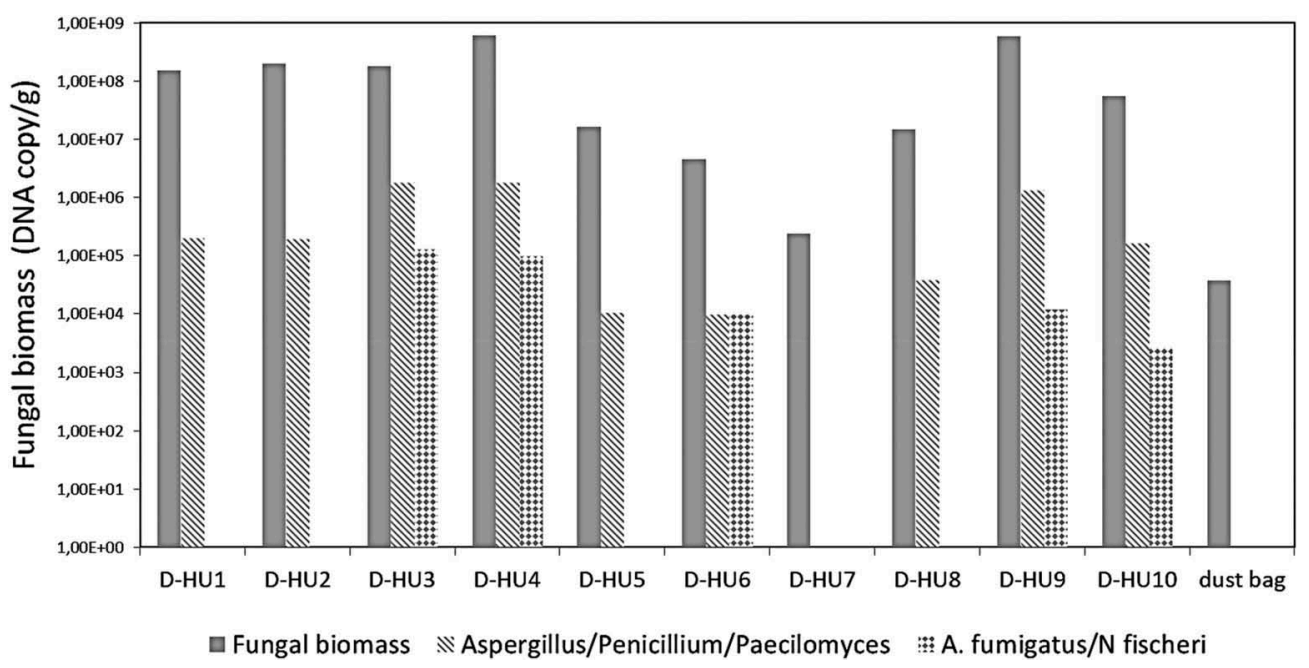

Figure 2. Fungal biomass, Aspergillus/Penicilliium/Paecilomyces and Aspergillus section Fumigati (A. fumigatus and N. fischeri) levels analyzed in the settled dust and the vacuuming dust bag samples.

\section{Discussion}

Bioburden in settled dust can become airborne (Chen and Hildemann 2009). When airborne, bioburden tends to aggregate into particles of different sizes depending on several variables such as source, microbial species, relative humidity and the aerosolization mechanism (Gralton et al. 2011). 
Table 8. Results of the Spearman correlation coefficient.

\begin{tabular}{|c|c|c|c|c|c|}
\hline Correlation Coefficient (p) & $\begin{array}{l}\text { Fungal biomass } \\
\text { levels }\end{array}$ & $\begin{array}{l}\text { Bacteria } \\
\text { counts }\end{array}$ & $\begin{array}{l}\text { Gram - } \\
\text { counts }\end{array}$ & $\begin{array}{c}\text { Fungal counts on } \\
\text { MEA }\end{array}$ & $\begin{array}{c}\text { Fungal counts on } \\
\text { DG18 }\end{array}$ \\
\hline $\begin{array}{l}\text { Dust weight used for } \\
\text { biomass }\end{array}$ & $-0.600(0.051)$ & $-0.316(0.344)$ & $0.047(0.892)$ & $-0.326(0.327)$ & $0.539(0.087)$ \\
\hline Fungal biomass levels & & $0.046(0.894)$ & $0.117(0.733)$ & $0.266(0.429)$ & $-0.384(0.244)$ \\
\hline Bacteria counts & & & $0.094(0.784)$ & $0.458(0.157)$ & $-0.106(0.757)$ \\
\hline Gram - counts & & & & $-0.105(0.758)$ & $0.262(0.436)$ \\
\hline Fungal counts on MEA & & & & & $0.164(0.630)$ \\
\hline
\end{tabular}

Previous studies suggested that the composition of bioburden indoors depends on activities of human occupants (Täubel et al. 2009; Lax et al. 2014). Similarly, there is evidence that mycobiota and bacteriota found indoors can be influenced by ventilation, building design, environmental characteristics (Meadow et al. 2014) or water infiltrations and damage (Emerson et al. 2015), and by the geographical location (Barberán et al. 2015). With so many factors influencing bioburden indoors, passive methods are likely more reliable than active methods to characterize bioburden since they can collect contamination from a longer period, thus, covering all the expected variations (Reponen 2017; Viegas 2018).

Settled dust reservoir has been described as able to predict bioburden levels in indoor air, being more reproducible than active methods (Leppänen et al. 2018), as it replicates the bioburden present in the indoor air. Several authors have reported the monitoring of bioaerosol by settled dust in hospitals as more representative for the evaluation of a long time exposure, because it includes the change in indoor activities and ventilation (Frankel et al. 2012), and it can be used as a quality control measure (Srikanth et al. 2008). Thus, sampling approach performed in indoor environments need to rely on more than one type of sample (Viegas et al. 2017; Leppänen et al. 2018) and settled dust should be included in sampling protocols to assess the exposure to bioburden.

Dust constitutes a microbial source in indoor environments (Osman et al. 2018), including the hospital environment (Sarica et al. 2002), and the resuspension of settled dust particles in the air is responsible to increase airborne bacterial load (Fröhlich-Nowoisky et al. 2009). Our results for bacterial levels in settled dust samples from PHCC were lower than those concerning other environments, namely, in domestic and specific occupational environments, such as homes with a reported average of $16 \times 10^{5} \mathrm{CFU}^{-1}$ (Horak et al. 1996) and $2.9 \times 10^{5}-4.9 \times 10^{7} \mathrm{CFU}^{-g^{-1}}$ (Frankel et al. 2012), and different agricultural environments, with bacterial loads up to $19-10^{9}$ CFU.g ${ }^{-1}$ (Shen et al. 1990). This can be due to the disinfection practices carried out in the assessed PHCC to achieve a proper surface disinfection, as a measure of preventing and controlling bacterial contamination, as suggested by all international guidelines for preventing infections (WHO 2002). However, fungi are more resistant to biocides than bacteria and biocides activity against fungi is not as well reported as their activity against bacteria (Sandle et al. 2014). Thus, although bacteria are less present in this indoor environment, visible fungal growth was observed.

The characterization of fungal distribution may indicate that a single genera dominates settled dust samples (Hicks et al. 2005). The dominant fungal species in this study (representing 50\% or more of the organisms cultured) was Penicillium sp. on MEA and Penicillium sp. and Cladosporium sp. on DG18, besides C. sitophila (fast growing fungi). These findings follow the same trend observed in a previous study performed in a different occupational environment (Viegas et al. 2018a), in which DG18 revealed a higher prevalence of Cladosporium sp., similar to other studies (Hicks et al. 2005), whereas MEA revealed a more diverse mycobiota. Indeed, DG18 restricts the colony size of fast growing genera (Bergwall and Stehn 2002), such as C. sitophila, therefore, enabling fungal growth of different species (Viegas et al. 2018c).

Aspergillus fumigatus sensu stricto and cryptic species, many resistant to antifungal drugs, are the most frequently observed in invasive aspergillosis (Latge 1999). Thus, it is of upmost 
importance to determine the prevalence and susceptibility to antifungal drugs of airborne fungi in different environments. Indeed, due the emergence of isolates of Aspergillus section Fumigati resistant to azoles, the European Center for Disease Control recommends the improvement of epidemiological surveillance and the investigation of the environmental origin through environmental and laboratory assessments, besides agricultural environments (Kleinkauf et al. 2013).

Fungal growth was observed for Chrysosporium sp. and Penicillium sp. in the different antifungal-supplemented media, and for Rhizopus sp. in voriconazole. Aspergillus section Fumigati growth was observed in Sabouraud but not in azole-supplemented media. Cryptic Aspergillus species might be underestimated, due to the presence of fast growing species, as abovementioned (Bergwall and Stehn 2002). Of note, in 3 out of the 10 assessed PHCC, fungal growth of Penicillium genera, comprising potential toxigenic species, was observed in both itraconazoleand voriconazole- supplemented media.

Whereas Rhizopus growth in voriconazole constitutes no surprise, as Mucorales are intrinsically resistant to Candida- and Aspergillus-active antifungal azole drugs, such as voriconazole (Macedo et al. 2018), Chrysosporium sp. and Penicillium sp. growth in azole-media can be due to the development of secondary resistance to azole-based antifungals (Eliopoulos et al. 2002). This is a significant clinical concern, as fungal infections with drug-resistant strains are difficult to treat. In high-risk patients (e.g. immunocompromised), the exclusion of azole-based antifungals due to resistance can dramatically limit drug choices for prophylaxis and first-line treatment of fungal invasive diseases and increase mortality rates for patients.

The antifungal susceptibility testing of strains that might be implicated in human infections, and also of toxigenic mycotoxin-producer strains, is recommended to evaluate the overall incidence of these species in clinical settings, and for a more accurate exposure risk characterization. Initial therapy should be guided not only by testing clinical isolates, but also by the knowledge of the environmental prevalence of azole-resistant strains in specific geographical regions and settings. Therefore, more environmental and clinical screening studies are necessary to generate the local epidemiologic data if such measures are to be implemented on a sound basis. Molecular methods should be used to evaluate isolates from screening studies, especially in the absence of cultured isolates.

Fungal biomass was effectively measured by the biomass assay, as in other studies (Marchand et al. 2017). All the obtained biomass levels were above the limit of detection, and were similar to the highest levels $\left(2.79 \times 10^{7}\right.$ spore.g-1)) described in a previous study conducted in deposited dust from ventilation systems in several work environments (Marchand et al. 2017). No correlation was found between data obtained from the fungal biomass assay and the culture based-methods. This might be due to an underestimation of fungal counts that seems to be the trend when applying culture-based methods (Degois et al. 2017), since they are dependent on fungal viability. Although viable part constitute only between 1 to $25 \%$ of total bioburden (Heikkila et al. 1988), culture-base methods are the gold standard and should always be applied to obtain information on cultivable and infectious organisms (Samson et al. 2000; Eduard and Halstensen 2009), being crucial in exposure assessment studies.

The use of the two different assays (culture based-methods and molecular tools) has given a more accurate scenario regarding fungal contamination. Indeed, dd-PCR analysis successfully detected Aspergillus section Fumigati in 4 sampling sites where culture base-methods could not identify this section. By qPCR we have detected Aspergillus section Versicolores in one sampling site, consistently with the results obtained from the culture-bases methods. However, none of the remaining species were detected by qPCR probably due to inhibition of PCR amplification as previously reported (Schrader et al. 2012) or even to incomplete DNA extraction. Noteworthy, fungi with reported toxigenic potential (Varga et al. 2015) were identified in settled dust samples and in vacuuming bag by culture based-methods: Penicillium sp. and Aspergillus sections Fumigati, Nigri and Versicolores, thus, corroborating the most common scenario of co-exposure 
to more than one risk factor - bioburden and metabolites (e.g. mycotoxins) (Viegas et al. 2018e) also in the clinical environment.

The presence of mycotoxins in clinical environments is not desirable since it represents an additional health risk factor for patients and workers. Unfortunately, mycotoxins are not commonly analyzed in samples from health care facilities and only one previous report has already reported mycotoxins data (Heutte et al. 2017). No correlations were found between mycotoxins contamination and specific cleaning routines, or other aspects able to explain the findings, since these were similar among all the assessed PHCC. In addition, no correlation was observed between total fungal load and mycotoxins levels. Similar to our findings, sterigmatocystin was already detected in a health care facility in 3 samples of bioaerosols at levels of $0.31,0.32$, and $1.45 \mu \mathrm{g}$ per $\mathrm{m}^{3}$ (Heutte et al. 2017). Although in a different matrix the values found were lower than the one found in our study. According to IARC classification, sterigmatocystin is a possible human carcinogen (2B) and show immunotoxic and immunomodulatory activity, together with mutagenic effects (McConnell and Garner 1994; Liu et al. 2014; Gao et al. 2015; Viegas et al. 2018d). The conclusion made by EFSA Panel on Contaminants in the Food Chain (CONTAM) (2013) was that the genotoxicity of sterigmatocystin is based on the formation of DNA adducts that, if unrepaired, increase the likelihood of mutation fixation (Viegas et al. 2018d).

The other mycotoxins detected in our study were never reported in health care facilities until now. Mycophenolic acid, detected in 2 samples, was the mycotoxin measured at higher concentration $\left(4.28 \mu \mathrm{g} \cdot \mathrm{kg}^{-1}\right)$ and is well known its immunosuppressive properties (Dasgupta 2016). This fungal secondary metabolite is produced by Penicillium species, being one of the most reported in settled dust samples (Egbuta et al. 2017). Also produced by Penicillium, roquefortine $\mathrm{C}$ and griseofulvin were also detected, although in lower amounts, being representative of the ability of a specific fungal species to produce many different mycotoxins (Frisvad et al. 2004).

Additional health risks may be observed as a result of co-exposure to multiple mycotoxins, as observed in 1 sample where 3 different mycotoxins were detected, corresponding to the most common exposure scenario: the simultaneous exposure to several mycotoxins that are often present in indoor environments (Assunção et al. 2015; Martins et al. 2018; Viegas et al. 2018e). These findings support the evidence that the indoor presence of a specific fungal species does not necessary imply the exposure to its specific mycotoxins, under specific environmental conditions (nutrients, temperature, humidity and others) fungi can indeed produce mycotoxins. Therefore, actions should be developed to prevent high levels of fungal contamination, particularly in clinical indoor settings where, besides health workers, immunocompromised patients can be present. Overall, the results obtained regarding mycotoxins presence allowed to recognize the importance to assess mycotoxins in health care facilities.

Air sampling, without the use in parallel of passive sampling, may be insufficient to adequately characterize the exposure to bioburden. This was already described in previous studies comparing settled dust and air samples, with different results for bioburden distribution (qualitative assessment) in settled dust and air samples (Cox et al. 2017), whereas in a different study significant quantitative correlations between airborne load and in settled dust were found (Frankel et al. 2012). If settled dust samples reveal very high concentrations of uncommon fungal genera (e.g. $>106 \mathrm{CFU} . \mathrm{g}^{-1}$ of toxigenic fungal species) as the dominant (more than $50 \%$ of prevalence) (Hicks et al. 2005), the collection of a large number of samples may not be necessary and harmful fungal contamination should be considered (Hicks et al. 2005). This would simplify the exposure assessment indoors, as settled dust is generally easier-to-use and less time-consuming to collect than airborne dust (Frankel et al. 2012).

In light of the results, it can be put in perspective that epidemiological registers regarding settled dust assessments, together with air sampling, will be valuable for comparison purposes in scenarios of high levels of bioburden contamination or even when nosocomial infections are reported. This collected information will support the Infection Control and Risk Assessment Committees to propose and implement the needed control measures in each PHCC, which can implicate more suitable cleaning procedures, altering the disinfection products, changing the frequency of cleaning 
or even the duration that a specific cleaning product is kept in contact with the surfaces to guarantee efficacy (Ruiz-Camps et al. 2011). Thus, a standardized settled dust collection should be included in protocols to assess indoor clinical environments, specifically PHCC.

\section{Conclusions}

Settling dust sampling in a routine way might provide useful information about bioburden exposure. This study also supports the importance of applying culture based-methods and molecular tools for the assessment of fungal burden. Settled dust represents the exposure over a longer period of time, representing the variation of a working day in indoor activities, being a reliable sampling method to achieve an accurate risk characterization regarding to bioburden exposure.

Our results emphasize the need to implement corrective measures to avoid the bioburden and mycotoxins contamination, and highlight the need for further studies addressing the same environmental parameters (bioburden and mycotoxins) in clinical environments. Eventually, the need to implement monitoring programs should be evaluated, as it will allow assessing the impact of the applied preventive measures.

\section{Acknowledgments}

The authors are grateful to FCT - Fundação para Ciência e Tecnologia for funding the project EXPOsE Establishing protocols to assess occupational exposure to microbiota in clinical settings (02/SAICT/2016 Project $n^{\circ}$ 23222).

\section{Conflict of Interest}

None.

We have full control of all primary data and permission is given to the journal to review the data if requested.

\section{Funding}

This work was supported by the Fundação para Ciência e Tecnologia [02/SAICT/2016 - Project no 23222].

\section{ORCID}

Beatriz Almeida (iD) http://orcid.org/0000-0002-2533-1397

João Cavaleiro Rufo (iD http://orcid.org/0000-0003-1175-242X

Liliana Aranha Caetano (iD http://orcid.org/0000-0003-1496-2609

\section{References}

Aleksic B, Draghi M, Ritoux S, Bailly S, Lacroix M, Oswald IP, Bailly J-D, Robinec E. 2017. Aerosolization of mycotoxins after growth of toxinogenic fungi on wallpaper. Appl Environ Microbiol. 83(16):1-12. doi:10.1128/ AEM.00653-17

Arendrup MC, Rodriguez-Tudela JL, Lass-Flörl C, Cuenca-Estrella M, Donnelly JP, Hope W. 2013. EUCAST technical note on anidulafungin. Clin Microbiol Infect. 19(6):278-280. doi:10.1111/1469-0691.12148.

Assunção R, Vasco E, Nunes B, Loureiro S, Martins C, Alvito P. 2015. Single-compound and cumulative risk assessment of mycotoxins present in breakfast cereals consumed by children from Lisbon region, Portugal. Food Chem Toxicol. 86:274-281. https://linkinghub.elsevier.com/retrieve/pii/S0278691515300867.

Badyda A, Gayer A, Czechowski P, Majewski G, Dąbrowiecki P. 2016. Pulmonary function and incidence of selected respiratory diseases depending on the exposure to ambient PM10. Int J Mol Sci. 22 17(11):1954. http:// www.mdpi.com/1422-0067/17/11/1954.

Barberán A, Dunn RR, Reich BJ, Pacifici K, Laber EB, Menninger HL, Morton JM, Henley JB, Leff JW, Miller SL, et al. 2015. The ecology of microscopic life in household dust. Proc R Soc B Biol Sci. 7 282(1814):20151139. http://rspb.royalsocietypublishing.org/lookup/doi/10.1098/rspb.2015.1139. 
Bergwall C, Stehn B. 2002. Comparison of selective mycological agar media for the isolation and enumeration of xerophilic moulds and osmotolerant yeasts in granulated white sugar. Zuckerindustrie. 127:259-264.

Bouillard L, Michel O, Dramaix M, Devleeschouwer M. 2005. Bacterial contamination of indoor air, surfaces, and settled dust, and related dust endotoxin concentrations in healthy office buildings. Ann Agric Environ Med. 12 (2):187-192. http://www.ncbi.nlm.nih.gov/pubmed/16457472.

Cabo Verde S, Almeida SM, Matos J, Guerreiro D, Meneses M, Faria T, Botelho D, Santos M, Viegas C. 2015. Microbiological assessment of indoor air quality at different hospital sites. Res Microbiol. doi:10.1016/j. resmic.2015.03.004

Chen Q, Hildemann LM. 2009. The effects of human activities on exposure to particulate matter and bioaerosols in residential homes. Environ Sci Technol. 43(13):4641-4646. doi:10.1021/es802296j.

Cox J, Indugula R, Vesper S, Zhu Z, Jandarov R, Reponen T. 2017. Comparison of indoor air sampling and dust collection methods for fungal exposure assessment using quantitative PCR. Environ Sci Process Impacts The Royal Soc Chem. 19(10):1312-1319. doi:10.1039/C7EM00257B.

Cruz-Perez P, Buttner MP, Stetzenbach LD. 2001. Detection and quantitation of Aspergillus fumigatus in pure culture using polymerase chain reaction. Mol Cell Probe. 15:81-88. doi:10.1006/mcpr.2000.0343

Dasgupta A. 2016. Personalized immunosuppression in transplantation role of biomarker monitoring and therapeutic drug monitoring. Pers Immunosuppression Transpl. (1st. Edition) 83-107.

De Hoog GS, Guarro J, Gebé J, Figueras MJ. 2000. Atlas of Clinical Fungi. ISBN: 90-70351-43-9, 2nd ed. Utrecht (The Netherlands): Centraalbureau voor Schimmelcultures.

Degois J, Clerc F, Simon X, Bontemps C, Leblond P, Duquenne P. 2017. First metagenomic survey of the microbial diversity in bioaerosols emitted in waste sorting plants. Ann Work Expo Heal. 61(9):1076-1086. doi:10.1093/ annweh/wxx075.

Dunn RR, Fierer N, Henley JB, Leff JW, Menninger HL. 2013. Home life: factors structuring the bacterial diversity found within and between homes. Bertilsson S, editor. PLoS One. 22 8(5):e64133. doi:10.1371/journal. pone. 0064133 .

Eduard W, Halstensen AS. 2009. Quantitative exposure assessment of organic dust. Scand J Work Environ Heal Suppl. 7:30-35.

Egbuta M, Mwanza M, Babalola O. 2017. Health Risks Associated with Exposure to Filamentous Fungi. Int J Environ Res Public Health. 4 14(7):719. http://www.mdpi.com/1660-4601/14/7/719.

Eliopoulos GM, Perea S, Patterson TF. 2002. Antifungal resistance in pathogenic fungi. Clin Infect Dis. 35 (9):1073-1080. doi:10.1086/344058.

Emerson JB, Keady PB, Brewer TE, Clements N, Morgan EE, Awerbuch J, Miller SL, Fierer N. 2015. Impacts of flood damage on airborne bacteria and fungi in homes after the 2013 Colorado front range flood. Environ Sci Technol. 3 49(5):2675-2684. doi:10.1021/es503845j.

EPA, United States Environmental Protection Agency 2017. About the national exposure research laboratory (NERL). [Accessed 2017 Jun 19]. http://www.epa.gov/nerlcwww/moldtech.htm $\square$.

Flannigan B. 1997. Air sampling for fungi in indoor environments. J Aerosol Sci. 28(3):381-392. http://linkinghub. elsevier.com/retrieve/pii/S0021850296004417.

Frankel M, Timm M, Hansen EW, Madsen AM. 2012. Comparison of sampling methods for the assessment of indoor microbial exposure. Indoor Air. 22(5):405-414. doi:10.1111/ina.2012.22.issue-5.

Frisvad JC, Smedsgaard J, Larsen TO, Samson RA. 2004. Mycotoxins, drugs and other extrolites produced by species in Penicillium subgenus Penicillium. Stud Mycol. 49:201-241.

Fröhlich-Nowoisky J, Pickersgill DA, Despres VR, Pöschl U. 2009. High diversity of fungi in air particulate matter. Proc Natl Acad Sci. 106:12814-12819. doi:10.1073/pnas.0811003106.

Gao W, Jiang L, Ge L, Chen M, Geng C, Yang G, Li Q, Ji F, Yan Q, Zou Y, et al. 2015. Sterigmatocysit-induced oxidative DNA damage in human liver-derived cell line through lysosomal damage. Toxicol in Vitro. 29:1-7. doi:10.1016/j.tiv.2014.08.007.

Gralton J, Tovey E, McLaws M-L, Rawlinson WD. 2011. The role of particle size in aerosolised pathogen transmission: A review. J Infect. 62(1):1-13. doi:10.1016/j.jinf.2010.11.010.

Halstensen AS, Nordby K-C, Eduard W, Klemsdal SS. 2006. Real-time PCR detection of toxigenic Fusarium in airborne and settled grain dust and associations with trichothecene mycotoxins. J Environ Monit. 8(12):1235. http://xlink.rsc.org/?DOI=b609840a.

Haugland RA, Brinkman N, Vesper SJ. 2002. Evaluation of rapid DNA extraction methods for the quantitative detection of fungi using real-time PCR analysis. J Microbiol Methods. 50:319-323.

Haugland RA, Varma M, Wymer LJ, Vesper SJ. 2004. Quantitative PCR analysis of selected Aspergillus, Penicillium and Paecilomyces species. Syst Appl Microbiol. 27(2):198-210. doi:10.1078/072320204322881826.

Heikkila P, Salmi T, Kotimaa M. 1988. Identification and counting of fungal spores by scanning electron microscopy. Ann Occup Hyg. 32:241-248. doi:10.1093/annhyg/32.2.241.

Heutte N, Andrï $i^{1 / 2}$ V, Dubos Arvis C, Bouchart V, Lemariï $i^{1 / 2}$ F, Legendre P, Votier E, Louis MY, Madelaine S2, Séguin V, et al. 2017. Assessment of multi-contaminant exposure in a cancer treatment center: a 2-year 
monitoring of molds, mycotoxins, endotoxins, and glucans in bioaerosols. Environ Monit Assess. 189(1). doi:10.1007/s10661-016-5751-z.

Hicks JB, Lu ET, De Guzman R, Weingart M. 2005. Fungal types and concentrations from settled dust in normal residences. J Occup Environ Hyg. 1 2(10):481-492. doi:10.1080/15459620500252860.

Hindson BJ, Ness KD, Masquelier DA, Belgrader P, Heredia NJ, Makarewicz AJ, Bright IJ, Lucero MY, Hiddessen AL, Legler TC. et al. 2011. High-throughput droplet digital PCR system for absolute quantitation of DNA Copy Number. Anal Chem. 15 83(22):8604-8610. Doi:10.1021/ac202028g

Hodgson M, Scott R. 1999. Prevalence of fungi in carpet dust samples. In: Johanning E, editor. Bioaerosols, fungi and mycotoxins: health effects, assessment, prevention and control. Albany (N.Y): Boyd Printing Company; p. 268-274.

Horak B, Dutkiewicz J, Solarz K. 1996. Microflora and acarofauna of bed dust from homes in Upper Silesia, Poland. Ann Allergy. Asthma Immunol. 76(1):41-50. http://linkinghub.elsevier.com/retrieve/pii/S1081120610634059.

Kettleson EM, Adhikari A, Vesper S, Coombs K, Indugula R, Reponen T. 2015. Key determinants of the fungal and bacterial microbiomes in homes. Environ Res. 138:130-135. doi:10.1016/j.envres.2015.02.003

Klánová K, Hollerová J. 2003. Hospital indoor environment: screening for micro-organisms and particulate matter. Ndoor Built Environ. 12(1-2):61-67. doi:10.1177/1420326X03012001010.

Kleinkauf N, Verweij P, Arendrup M, Donnelly P, Cuenca-Estrella M, Fraaije B, Melchers W, Adriaenssens N, Kema G, Ullmann A, et al. 2013. Risk assessment on the impact of environmental usage of triazoles on the development and spread of resistance to medical triazoles in Aspergillus species. Stockholm. doi:10.2900/76274

Lamoth F. 2016. Aspergillus fumigatus-related species in clinical practice. Front Microbiol. 7:683. doi:10.3389/ fmicb.2016.00683.

Latge JP. 1999. Aspergillus fumigatus and aspergillosis. Clin Microbiol Rev. 12:310-350. doi:10.1128/CMR.12.2.310.

Lax S, Smith DP, Hampton-Marcell J, Owens SM, Handley KM, Scott NM, Gibbons SM, Larsen P, Shogan BD, Weiss S, Metcalf JL, Ursell LK, Vázquez-Baeza Y. et al. 2014. Longitudinal analysis of microbial interaction between humans and the indoor environment. Science. 29 345(6200):1048-1052. doi:10.1126/science.1254529

Leppänen HK, Nevalainen A, Vepsäläinen A, Roponen M, Täubel M, Laine O, Rantakokko P, von Mutius E, Pekkanen J, Hyvärinen A. 2014. Determinants, reproducibility, and seasonal variation of ergosterol levels in house dust. Indoor Air. 24(3):248-259. doi:10.1111/ina.12078.

Leppänen HK, Täubel M, Jayaprakash B, Vepsäläinen A, Pasanen P, Hyvärinen A. 2018. Quantitative assessment of microbes from samples of indoor air and dust. J Expo Sci Environ Epidemiol. 4 28(3):231-241. doi:10.1038/ jes.2017.24

Leung M, Chan AHS. 2006. Control and management of hospital indoor air quality. Med Sci Monit. 12(3):SR17SR23. http://www.ncbi.nlm.nih.gov/pubmed/16501436.

Liu Y, Du M, Zhang G. 2014. Proapoptotic activity of aflatoxin B 1 and sterigmatocystin in HepG2 cells. Toxicol Reports. 1:1076-1086. https://linkinghub.elsevier.com/retrieve/pii/S2214750014001139.

Macedo D, Leonardelli F, Dudiuk C Theill L, Cabeza MS, Gamarra S, Garcia-Effron G. 2018. Molecular Confirmation of the Linkage between the Rhizopus oryzae CYP51A gene coding region and its intrinsic voriconazole and fluconazole resistance. Antimicrob Agents Chemother. 27 62(8). doi:10.1128/AAC.00224-18.

Marchand G, Duchaine C, Lavoie J, Veillette M, Cloutier Y. 2016. Bacteria emitted in ambient air during bronchoscopy - a risk to health care workers? Am J Infect Control. 44(12):1634-1638. https://linkinghub.else vier.com/retrieve/pii/S0196655316304989.

Marchand G, Lacombe N, Pépin C. 2017. Évaluation de la biomasse mycologique sur les surfaces des réseaux aérauliques des systèmes de ventilation. Quebec: Institut de recherche Robert-Sauvé en santé et en sécurité du travail. (Rapports Scientifiques: DesLibris). https://books.google.pt/books?id=4A_BswEACAAJ.

Martins C, Assunção R, Cunha SC, Fernandes JO, Jager A, Petta T, Oliveira CA, Alvito P. 2018. Assessment of multiple mycotoxins in breakfast cereals available in the Portuguese market. Food Chem. 239:132-140. https:// linkinghub.elsevier.com/retrieve/pii/S0308814617310701.

Mayer Z, Bagnara A, FaÅNrber P, Geisen R. 2003. Quantification of the copy number of nor-1, a gene of the aflatoxin biosynthetic pathway by real-time PCR, and its correlation to the cfu of Aspergillus flavus in foods. Int J Food Microbiol. 82:143-151. doi:10.1016/S0168-1605(02)00250-7

McConnell IR, Garner RC. 1994. DNA adducts of aflatoxins, sterigmatocystin and other mycotoxins. IARC Sci Publ. (125):49-55. http://www.ncbi.nlm.nih.gov/pubmed/7806340.

Meadow JF, Altrichter AE, Kembel SW, Kline J, Mhuireach G, Moriyama M, Northcutt D, O'Connor TK, Womack AM, Brown GZ. et al. 2014. Indoor airborne bacterial communities are influenced by ventilation, occupancy, and outdoor air source. Indoor Air. 24(1):41-48. doi:10.1111/ina.12047.

Meyer HW, Würtz H, Suadicani P, Valbjørn O, Sigsgaard T, Gyntelberg F. 2004. Molds in floor dust and building-related symptoms in adolescent school children. Indoor Air. 14(1):65-72. doi:10.1046/j.16000668.2003.00213.x.

Perlin DS. 2017. Stop neglecting fungi. Nat Microbiol. 25;2(8):17120. http://www.nature.com/articles/ nmicrobiol2017120. 
Nevalainen A, Täubel M, Hyvärinen A. 2015. Indoor fungi: companions and contaminants. Indoor Air. 25 (2):125-156. doi:10.1111/ina.12182.

Osman M, Ibrahim H, Yousef F, Elnasr AA, Saeed Y, Hameed AA. 2018. A study on microbiological contamination on air quality in hospitals in Egypt. Indoor Built Environ. 2 27(7):953-968. doi:10.1177/ $1420326 X 17698193$.

Park DU, Yeom JK, Lee WJ, Lee KM. 2013. Assessment of the levels of airborne bacteria, gram-negative bacteria, and fungi in hospital lobbies. Int J Environ Res Public Health. 10(2):541-555. doi:10.3390/ijerph10020541.

Park J-H, Sulyok M, Lemons AR, Green BJ, Cox-Ganser JM. 2018. Characterization of fungi in office dust: comparing results of microbial secondary metabolites, fungal internal transcribed spacer region sequencing, viable culture and other microbial indices. Indoor Air. 28(5):708-720. doi:10.1111/ina.2018.28.issue-5.

Reponen T. 2017. Sampling for microbial determination. In: In VC, Viegas S, Quintal GA, Taubel M, Sabino R, editors. Exposure to microbiological agents in indoor and occupational environments. SpringerNature. 85-96. doi:10.1007/978-3-319-61688-9

Ruiz-Camps I, Aguado JM, Almirante B, Bouza E, Ferrer-Barbera CF, Len O, Lopez-Cerero L, Rodríguez-Tudela JL, Ruiz M, Solé A. et al. 2011. Guidelines for the prevention of invasive mould diseases caused by filamentous fungi by the Spanish Society of Infectious Diseases and Clinical Microbiology (SEIMC). Clin Microbiol Infect. 7:1-24. doi:10.1111/j.1469-0691.2011.03477.x

Samson RA, Hoekstra ES, Frisvad JC 2000. Introduction to food- and airborne fungi 6th rev. e. Utrecht : Centraalbureau voor schimmelcultures. http://lib.ugent.be/catalog/rug01:000698898.

Sandle T, Vijayakumar R, Saleh Al Aboody M, Saravanakumar S. 2014. vitro fungicidal activity of biocides against pharmaceutical environmental fungal isolates. J Appl Microbiol. 117:1267-1273. doi:10.1111/jam.12525.

Sarıca S, Asan A, Otkun MT, Ture M. 2002. Monitoring indoor airborne fungi and bacteria in the different areas of trakya university hospital, Edirne, Turkey. Indoor Built Environ. 11:285-292. doi:10.1159/000066523

Schrader C, Schielke A, Ellerbroek L, Johne R. 2012. PCR inhibitors - occurrence, properties and removal. J Appl Microbiol. 113(5):1014-1026. doi:10.1111/jam.2012.113.issue-5.

Shen YE, Sorenson WG, Lewis DM, Olenchock SA. 1990. Microbiological analyses and inflammatory effects of settled dusts from rice and hay. Biomed Environ Sci.3. 3:353-363. http://www.ncbi.nlm.nih.gov/pubmed/2252555.

Srikanth P, Sudharsanam S, Steinberg R. 2008. Bio-aerosols in indoor environment: composition, health effects and analysis. Indian J Med Microbiol. 26(4):302. http://www.ijmm.org/text.asp?2008/26/4/302/43555.

Tang C-S, Wan G-H. 2013. Air quality monitoring of the post-operative recovery room and locations surrounding operating theaters in a medical center in Taiwan. Conly J, editor. PLoS One. 3 8(4):e61093. doi:10.1371/journal. pone.0061093.

Tangni EK, Pussemier L. 2007. Ergosterol and mycotoxins in grain dusts from fourteen Belgian cereal storages: A preliminary screening survey. J Sci Food Agric. 87(7):1263-1270. doi:10.1002/jsfa.2838.

Täubel M, Rintala H, Pitkäranta M, Paulin L, Laitinen S, Pekkanen J, Hyvärinen A, Nevalainen A. 2009. The occupant as a source of house dust bacteria. J Allergy Clin Immunol. 124(4):834-840.e47. http://linkinghub. elsevier.com/retrieve/pii/S0091674909011543.

Varga J, Baranyi N, Chandrasekaran M, Vágvölgyi C, Kocsubé S. 2015. Mycotoxin producers in the Aspergillus genus: an update. Acta Biol Szeged. 59:151-167.

Viegas C. 2018. ISBN: 978-1- 138-54203-7. Sampling methods for an accurate mycobiota occupational exposure assessment - overview of several ongoing projects. In Occupational Safety and Hygiene VI Arezes et al. (Eds.). London: CRC Press. Taylor and Francis Group. 7-11.

Viegas C, Faria T, Caetano LA, Carolino E, Gomes AQ, Viegas S. 2017. Aspergillus spp. prevalence in different Portuguese occupational environments: what is the real scenario in high load settings? J Occup Environ Hyg. 14 (10):771-785.

Viegas C, Faria T, Monteiro A, Aranha Caetano L, Carolino E, Quintal Gomes A, Viegas S. 2018a. A novel multiapproach protocol for the characterization of occupational exposure to organic dust-swine production case study. Toxics. 6:5. doi:10.3390/toxics6010005

Viegas C, Malta-Vacas J, Sabino R 2012. Molecular biology versus conventional methods-complementary methodologies to understand occupational exposure to fungi. International Symposium on Occupational Safety and Hygiene SHO. Guimarães, Portugal. doi:10.1094/PDIS-11-11-0999-PDN

Viegas C, Monteiro A, Aranha Laetano L, Faria T, Carolino E, Viegas S. 2018b. Electrostatic dust cloth: A passive screening method to assess occupational exposure to organic dust in bakeries. Atmosphere. 9(2):1-14. doi:10.3390/atmos9020064.

Viegas C, Monteiro A, Dos Santos M, Faria T, Aranha CL, Carolino E, Quintal Gomes A, Marchand G, Lacombe N, Viegas S. 2018c. Filters from taxis air conditioning system: A tool to characterize driver's occupational exposure to bioburden? Environ Res. 164:522-529. doi:10.1016/j.envres.2018.03.032.

Viegas C, Nurme J, Pieckova E, Viegas S. 2018d. Sterigmatocystin in foodstuffs and feed: aspects to consider. Mycology. doi:10.1080/21501203.2018.1492980 
Viegas C, Ramos C, Almeida M, Sabino R, Veríssimo C, Rosado L. 2011. Air fungal contamination in ten hospitals' food units from Lisbon. In: WIT Transactions on Ecology and the Environment. p. 127-132. http://library. witpress.com/viewpaper.asp?pcode=FENV11-013-1.

Viegas S, Assunção R, Nunes C, Osteresch B, Twaruzek M, Kosicki R, Grajewski J, Martins C, Alvito P, Almeida A, et al. 2018e. Exposure assessment to mycotoxins in a portuguese fresh bread dough company by using a multi-biomarker approach. Toxins. 10. p. 342. doi:10.3390/toxins10090342.

World Health Organization (WH). 2016. Antimicrobial resistance: fact sheet no 194. Genebra: WHO. http://www. who.int/mediacentre/factsheets/fs194/en/.

World Health Organization (WHO). 2002. Prevention of hospital-acquired infections A PRACTICAL GUIDE. 2nd. France: WHO/CDS/CSR/EPH/2002.12. 72. http://www.who.int/emc\%0Ahttp://apps.who.int/medicinedocs/docu ments/s16355e/s16355e.pdf. 